\title{
DETECTION OF PARVOVIRUS B19 INFECTION IN FORMALIN-FIXED AND PARAFFIN-EMBEDDED PLACENTA AND FETAL TISSUES
}

\author{
Paulo Roberto Veiga QUEMELO(1), Danielle Malta LIMA(2), Benedito Antônio Lopes da FONSECA(2) \& Luiz Cesar PERES(1)
}

\begin{abstract}
SUMMARY
Parvovirus B19 infection was first discovered in 1975 and it is implicated in fetal death from hydrops fetalis the world over. Diagnosis is usually made through histological identification of the intranuclear inclusion in placenta and fetal organs. However, these cells may be scarce or uncharacteristic, making definitive diagnosis difficult. We analyzed histologically placentas and fetal organs from 34 cases of non-immune hydrops fetalis, stained with Hematoxylin and Eosin (HE) and submitted to immunohistochemistry and polymerase chain reaction (PCR). Of 34 tissue samples, two (5.9\%) presented typical intranuclear inclusion in circulating normoblasts seen in Hematoxylin and Eosin stained sections, confirmed by immunohistochemistry and PCR. However, PCR of fetal organs was negative in one case in which the placenta PCR was positive. We concluded that parvovirus B19 infection frequency is similar to the literature and that immunohistochemistry was the best detection method. It is highly specific and sensitive, preserves the morphology and reveals a larger number of positive cells than does HE with the advantage of showing cytoplasmic and nuclear positivity, making it more reliable. Although PCR is more specific and sensitive in fresh or ideally fixed material it is not so in formalin-fixed paraffin-embedded tissues, frequently the only one available in such cases.
\end{abstract}

KEYWORDS: Immunohistochemistry; Hydrops fetalis; Parvovirus B19.

\section{INTRODUCTION}

Parvovirus B19, the virus responsible for the erythema infectiosum, was discovered in the U.K. in 1975 by COSSART et al., who identified the virus in the serum of a healthy blood donor ${ }^{5}$. It is the only pathogenic human virus belonging to the Parvoviridae family and having a worldwide distribution ${ }^{2}$.

Transmission of the virus is through airway secretions and blood ${ }^{2,17}$. In temperate countries, infection is more common from the end of winter to the beginning of summer and there are spikes in frequency every three to four years ${ }^{1,28}$, a finding also reported in a study from Rio de Janeiro, Brazil ${ }^{24}$.

The percentage of individuals that have come into contact with the parvovirus B19 virus increases in parallel with the age of the individual, reaching $75 \%$ by the age of $50^{4,28}$. In Rio de Janeiro, Brazil, IgG for parvovirus B19 was detected in 35\% of children under five years of age, in $80 \%$ of teenagers from 11 to 15 and in over $90 \%$ of adults older than $50^{23}$.

Although post-natal parvovirus B19 infection is usually mild, either completely asymptomatic or manifested by erythema infectiosum, fever, arthropathy, malaise or myalgia ${ }^{3,19,13}$ the disease may be life-threatening during fetal life. Vertical transmission, which occurs in over $30 \%$ of cases $^{3,28}$, may result in fetal hydrops or abortion ${ }^{9,26,33}$. The virus replicates in erythroid precursors ${ }^{2,10,22}$, resulting in anemia. More recently, it has been shown to infect cardiomyocytes ${ }^{25}$, which, together with the anemia, can induce heart failure and fetal hydrops.

Diagnosis of parvovirus B19 infection in formalin-fixed, paraffin embedded tissue can be made through the identification of the characteristic brick-red intranuclear inclusions in normoblasts within the fetal circulation in histological sections stained with Hematoxylin and Eosin $(\mathrm{HE})^{29}$, by immunohistochemistry ${ }^{20,32}$ or by PCR ${ }^{15,21,28}$. These methods differ in respect to ease of use, cost, sensitivity and specificity, all of which must be taken into account when selecting a technique for routine diagnostic use.

The present study aimed to determine the frequency of parvovirus B19 infection in cases of non-immune fetal hydrops or diffuse villous edema in the placenta in tissues fixed in formalin and embedded in paraffin examined at the Ribeirão Preto School of Medicine University Hospital using the three aforementioned methods.

Study conducted in the Departments of Pathology and Internal Medicine, Ribeirão Preto School of Medicine, Av. Bandeirantes 3900, 14049-900 Ribeirão Preto, SP, Brazil. Grant support: CAPES (Coordenadoria do Pessoal do Ensino Superior) and FAEPA (Fundação de Apoio ao Ensino, Pesquisa e Assistência)

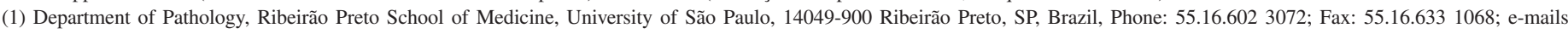
pquemelo@hotmail.com; lcperes@fmrp.usp.br

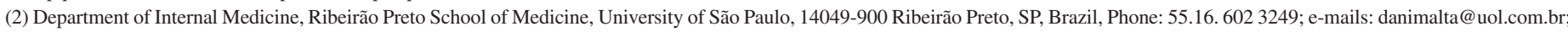
baldfons@fmrp.usp.br

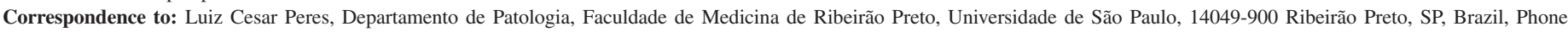
55.16.3602 3123; Fax: 55.16.3633 1068; email: lcperes@fmrp.usp.br 


\section{MATERIAL AND METHODS}

The Ethical Research Committee of the Ribeirão Preto School of Medicine University Hospital approved this study (No. 3830/2003).

A total of 34 formalin-fixed, paraffin-embedded tissue samples were used, of which 26 were placentas from well-formed fetuses with non-immune hydrops, and eight were tissue fragments obtained through curettage. The latter presented diffuse villous edema and few or no fetal fragments. The patients from whom the samples were collected had been previously examined at the University Hospital from January 1998 to December 2002.

Two $4 \mu \mathrm{m}$-thick histological sections were taken from each case for $\mathrm{HE}$ and immunohistochemical staining, respectively, the latter over silane-coated slides.

Antigenic retrieval using steam heat in $\mathrm{pH} 6.0$ citrate buffer was employed for the immunohistochemical reaction with R92F6 parvovirus B19 primary antibody (NCL-Parvo, Novocastra, Newcastle upon Tyne, UK), diluted 1:1500 in BSA and incubated overnight. Subsequently, the sections were incubated with the secondary antibody (biotinylated, affinity-purified anti-immunoglobulin; Novocastra, Newcastle upon Tyne, UK) diluted 1:200 in BSA for 60 minutes. Immunolabelling was performed by a standard Avidin-Biotin (ABC) technique (Novostain Super ABC Kit, universal, Novocastra Laboratories, U.K.). The labeling was developed with 3,3'-diaminobenzidine (DAB; D5638, Sigma, St. Louis, MO, USA) and the slides were counterstained with Harris hematoxylin and mounted with Entellan (Merck, USA).

Histological sections (each $5 \mu \mathrm{m}$-thick) were cut, using a new, clean disposable knife for each section, and collected into new clean 1.5-mL microtubes for PCR. Paraffin was removed by three xylene and two absolute ethanol washes, followed by DNA extraction with Wizard ${ }^{\circledR}$ Genomic DNA Purification Kit (Promega Corporation, Madison, WI, USA). DNA was quantified with a BECKMAN DU-600 spectrophotometer.

As a control for DNA integrity in the PCR amplification reactions, the endogenous mammalian $\beta$-globin gene was also amplified with a pair of $\beta$-globin-specific oligonucleotide primers ${ }^{8}$.

The DNA amplification was performed as follows: $5 \mu \mathrm{L}$ of DNA, $23 \mu \mathrm{L}$ of PCR SUPERMIX (55 mM Kcl, $1.65 \mathrm{mM} \mathrm{MgCl} 2,220 \mu \mathrm{M}$ dGTP, $220 \mu \mathrm{M}$ dATP, $220 \mu \mathrm{M}$ dCTP, $220 \mu \mathrm{M}$ dTTP, 22 U recombinant TAQ DNA Poly/Ml, Stabilizers), $1 \mu \mathrm{L}$ of sense primer B19-1, CAA AAG CAT GTG GAG TGA GG (nucleotides 3187 through 3206) and $1 \mu \mathrm{L}$ of antisense primer B19-2, CCT TAT AAT GGT GCT CTG GG (nucleotides 3290 through 3271) were added and put into an Applied Biosystems Thermocycler, with the following cycle definitions: $94{ }^{\circ} \mathrm{C} /$ 5 minutes; $94{ }^{\circ} \mathrm{C} / 1$ minute, $50{ }^{\circ} \mathrm{C} / 1.5$ minutes, $72{ }^{\circ} \mathrm{C} / 1$ minute $(35$ repetitions after second step), and, finally, $72{ }^{\circ} \mathrm{C}$ for five minutes, obtaining a 104-bp fragment.

Phosphate-buffered saline was used as a negative control and a sample obtained from a child with a known acute PB19 infection was used as a positive control.
Following amplification, the material was submitted to agarose gel electrophoresis (Gibco) in TBE at $80 \mathrm{~V}$ for one hour, stained with ethidium bromide, and then photographed.

\section{RESULTS}

Of the 34 cases analyzed, recognizable fetuses were observed in 22. Of those 22,12 were female and 10 were male. The fetuses were hydropic but presented no other external or internal abnormalities. In four cases, there were only fragments of placenta and fetuses, and there was therefore no possibility of macroscopic sex assignment. The remaining eight cases were represented only by fragments of placenta. Gestational age ranged from nine to 40 weeks and fetal weight from 34 to $1527 \mathrm{~g}$.

Light microscopy of the placentas of all cases revealed diffuse villous edema with numerous normoblasts in fetal circulation. Of the 34 cases studied, two $(5.9 \%)$ presented some normoblasts with the characteristic parvovirus B19 brick-red intranuclear inclusion seen in the HE-stained sections (Fig. 1A). In the same two cases, the
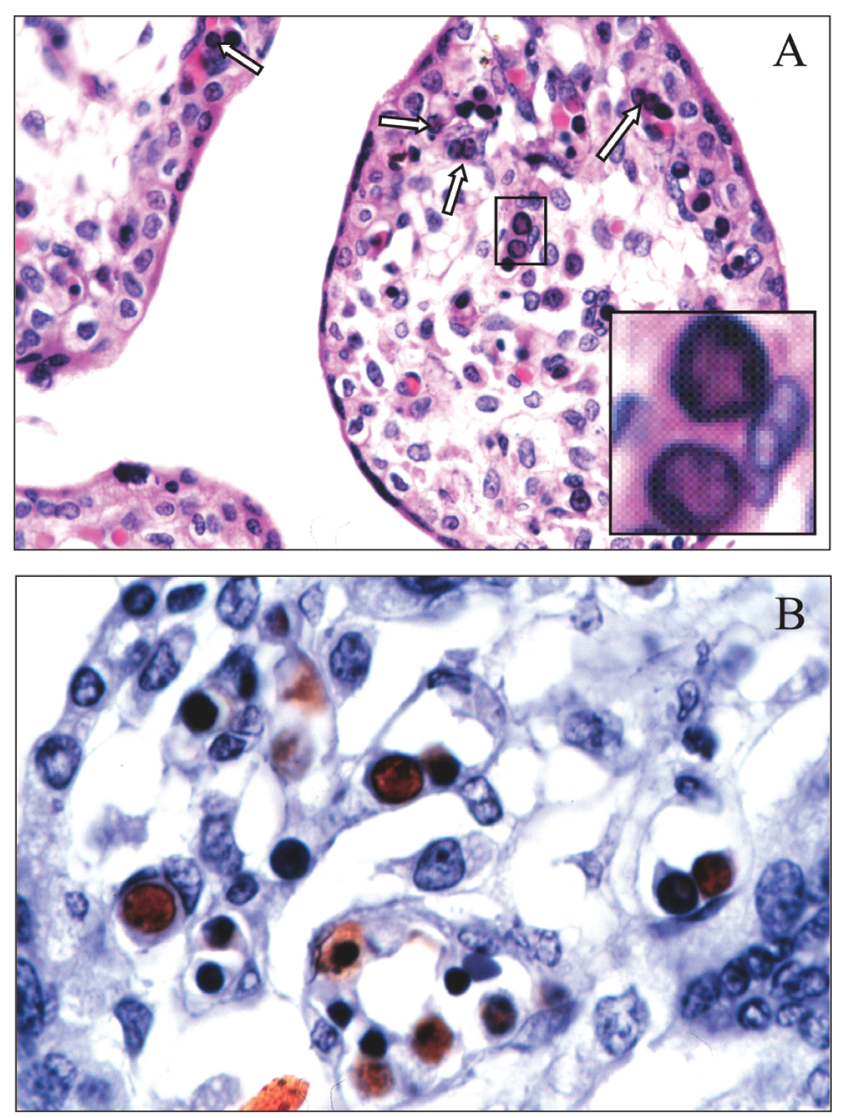

Fig. 1 A - Photomicrography of the hematoxylin and eosin (HE)-stained placenta in one of the positive cases of parvovirus B19 infection. Note the brick-red intranuclear inclusions (arrows) in the cells of capillaries in the chorionic villi, better seen in the inset (original magnification, 40x). B - Immunohistochemical staining of parvovirus B19 infected cells with R92F6 primary antibody. Note cytoplasmic and nuclear labeling seen in a larger number of cells than that observed in the HE-stained sections (ABC technique, DAB substrate, Hematoxylin counterstain. Original magnification, 40x) 
Table 1

Clinical and laboratory test data from the two parvovirus B19-positive cases

\begin{tabular}{lllllll}
\hline Case \# & Malformation & GA & Sex & Weight & Necropsy finding & Histopathological finding \\
\hline 1 & No & 19 & M & $720 \mathrm{~g}$ & Hydrops fetalis, grade II maceration & $\begin{array}{l}\text { Circulating normoblasts in placenta } \\
\text { and fetal organs, some with nuclear } \\
\text { inclusion. Diffuse villous edema. }\end{array}$ \\
\hline 2 & No & 27 & F & $1521 \mathrm{~g}$ & Hydrops fetalis, grade II maceration & $\begin{array}{l}\text { Circulating normoblasts in placenta } \\
\text { and fetal organs, some with nuclear } \\
\text { inclusion. Diffuse villous edema. }\end{array}$ \\
\hline
\end{tabular}

GA, gestational age; M, Male; F, Female; g, gram.

immunohistochemical reaction using R92F6 parvovirus B19 primary antibody was positive in the cytoplasm and nucleus (Fig. 1B), as was the PCR (Fig. 2). When these methods were applied to histological sections of fetal organs (heart, lung, kidney and liver) the same two cases tested positive for parvovirus B19 in the immunohistochemical and histological analyses, although PCR only showed positivity in one. No other cell type seen inside fetal vessels, apart from hemopoietic cells, showed positivity for parvovirus B19. All tissues contained amplifiable $\beta$-globin DNA (data not shown).

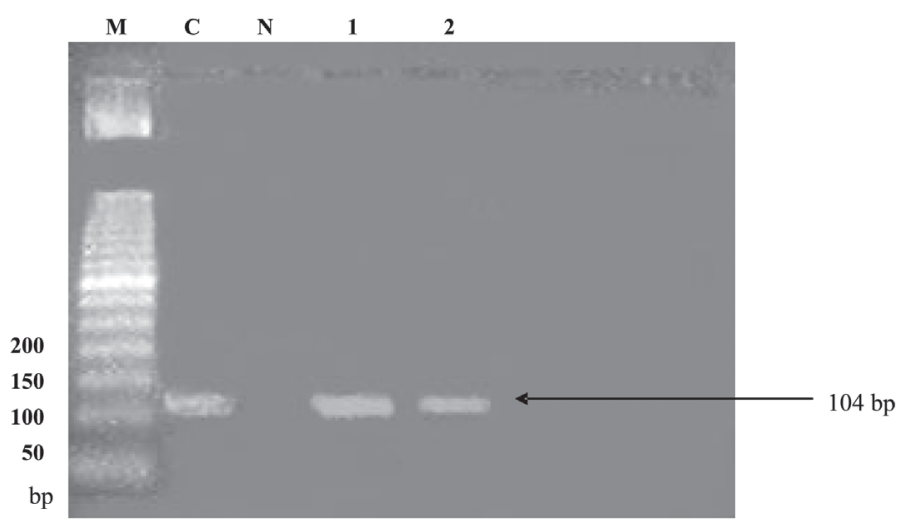

Fig. 2 - PCR of the placenta of the two parvovirus B19 infected cases. (M, ladder; C, positive control; $\mathrm{N}$, negative control; 1 , case one; 2 , case 2).

Results of clinical and laboratory testing of the two positive cases are summarized in Table 1, and the various methods are compared in Table 2.

\section{DISCUSSION}

Infection with parvovirus B19 is common in the general population. The serological prevalence ranges from $75 \% \%^{4,28}$ to over $90 \%{ }^{23}$ in adults aged 50 or older, and the infection usually presents as a mild selflimited disease ${ }^{11}$. Due to the risk of fetal contamination, serious consequences may ensue during the childbearing years in women ${ }^{14,19,28}$. In 1995, GRATACÓS et al. ${ }^{11}$ found a $35.03 \%$ prevalence of antiparvovirus $\mathrm{B} 19 \mathrm{IgG}$ and $3.7 \% \mathrm{IgM}$ antibodies in pregnant women at less than 28 weeks of gestation examined at the Hospital de Clínicas de Barcelona. In Rio de Janeiro, Brazil, CUBEL et al. tested 28 cases of non-immune fetal hydrops for parvovirus B19 infections with different techniques and found six positive cases, one of which had also a previous diagnosis of syphilis ${ }^{6}$.
Table 2

Result of the investigation of parvovirus B19 with the various tissues and techniques used

\begin{tabular}{|c|c|c|c|c|c|c|}
\hline \multirow[b]{3}{*}{ Tissue } & \multicolumn{6}{|c|}{ Case \# } \\
\hline & \multicolumn{3}{|c|}{1} & \multicolumn{3}{|c|}{2} \\
\hline & $\mathrm{HE}$ & IH & PCR & $\mathrm{HE}$ & IH & PCR \\
\hline Placenta & + & + & + & + & + & + \\
\hline Heart & + & + & + & + & + & - \\
\hline Liver & + & + & + & + & + & - \\
\hline Lungs & + & + & + & + & + & - \\
\hline Kidneys & + & + & + & + & + & - \\
\hline
\end{tabular}

HE, Hematoxylin and Eosin; IH, Immunohistochemistry; PCR, polymerase chain reaction.

In the present study, two out of 34 cases were positive, resulting in a prevalence of $5.9 \%$ which is within the range of $4 \%$ to $16 \%$ reported in the literature ${ }^{7,28}$. Also in accordance with the literature, the two positive cases were also second trimester $\operatorname{cases}^{6,24,29}$. The peak in incidence of parvovirus B19 infection and consequent hydrops in the second trimester is explained by the substantial increase in blood cell production and the decrease in fetal tolerance for anemia due to a small hematological reserve $\mathrm{e}^{27,29,30}$. Therefore, the second trimester represents the best opportunity for clinical diagnosis ${ }^{11,29,32}$. With the advent of molecular diagnosis, peak incidence of parvovirus B19 infection has shifted to the end of the third trimester, probably due to the higher sensitivity of this technique ${ }^{28}$.

The deleterious action of parvovirus B19 is seen when pregnant women are infected and the fetus becomes involved. The parvovirus B19 replicates in red blood cell precursors ${ }^{2,14,22}$ leading to decreased production of these cells and, consequently, anemia and myocardial failure. Infected cells present a characteristic brick-red intranuclear inclusion seen in HE-stained histological sections, as was observed in our cases (Fig. 1A).

In the present study, as in most previous studies of such cases, the only significant findings were fetal hydrops, grade II maceration and hydropic villi ${ }^{9}$, although there have been reports implicating parvovirus $\mathrm{B} 19$ in other conditions. WEILAND et al.$^{31}$ reported a case of parvovirus B19, diagnosed by dot-blot hybridization, that presented microphthalmia and lack of an iris and anterior chamber. In contrast, TOLFVENSTAM et $a l .{ }^{28}$ described cases that were either undetectable with laboratory test or presented no fetal hydrops or malformation. 
Furthermore, WRIGHT et al. ${ }^{32}$ reported cases that presented cardiac dilatation, excess lipid accumulation in the adrenal cortex, excessive iron deposition in the liver and increased placental volume and weight.

Although the replication of parvovirus B19 usually occurs in red blood cell precursors, recent studies have shown that this virus can also infect myocardial cells and thus contribute to the heart failure ${ }^{25}$. In our cases, employing immunohistochemical and histological analysis of the placenta and fetal organs, we found that red blood cell precursors were the only cells infected with parvovirus B19.

Most parvovirus B19-infected cells can be identified through careful histological examination by an experienced pathologist. However, immunohistochemical staining highlights a larger number of positive cells than does HE staining. In addition, since positivity has been found in the cytoplasm ${ }^{20,32}$ as well as in the nucleus, the efficiency of immunohistochemistry may increase in studies with larger samples.

The PCR method is known to be highly specific and sensitive, although some difficulties arise in formalin-fixed and paraffinembedded tissue ${ }^{16}$, as evidenced by the negative result in the fetal organs (although positive in the placenta) in one of our cases.

Due to crosslinking with proteins, which increases with the duration of fixation, formalin fixation may damage the DNA ${ }^{16}$. Contamination is a serious problem, and precautions, such as the use of surgical masks and gloves, should therefore be taken ${ }^{18}$. Finally, the identification of which cells are involved in the process is lost with this method.

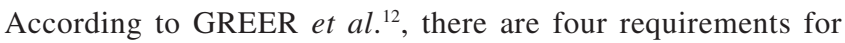
successful PCR in paraffin-embedded tissue: proper fixative, proper duration of fixation, proper age of the paraffin block, and proper length of the DNA fragment to be amplified. We have discovered that section thickness is also important, probably due to the amount of paraffin and proteins that are not completely eliminated and thereby impair both the extraction and amplification process.

Despite the small number of positive cases in this study, histological examination of HE-stained sections allowed the identification of the same affected cases, but with fewer cells and only the ones with intranuclear inclusion. Although the low cost, its use in routine diagnosis as a single method of detection is time consuming, more prone to underdiagnosis and demands well-trained persons. Although PCR is more specific and sensitive in material that is fresh or ideally fixed ${ }^{28}$, it is not so in formalin-fixed and paraffin-embedded tissues and has the additional disadvantage of destroying the histological structure. Immunohistochemistry is highly specific and sensitive, preserves the morphological characteristics and reveals a larger number of positive cells than that seen with HE staining, and has the advantage of revealing cytoplasmic and nuclear positivity, making it a more reliable tool for investigation and diagnosis of parvovirus B19 infection.

\section{RESUMO}

\section{Detecção da infecção pelo parvovírus B19 em placenta e tecidos fetais fixados em formalina e embebidos em parafina}

O parvovírus B19 foi detectado em 1975 e desde sua descoberta tem se mostrado um agente infeccioso importante em seres humanos, cujo diagnóstico pode ser feito pelo exame histológico através do encontro de inclusão nuclear em tecidos fetais ou placentários. No entanto, estas células podem ser escassas ou não apresentarem características típicas, dificultando o diagnóstico. Analisamos placentas e órgãos fetais de 34 casos de hidropisia fetal não-imune corados com Hematoxilina e Eosina (HE) e submetidos à reação em cadeia da polimerase (PCR) e imuno-histoquímica (IH). Em dois casos $(5,9 \%)$ houve positividade na placenta pelo HE, IH e PCR. No entanto, PCR dos órgãos fetais foi negativa em um destes casos enquanto que a identificação pôde ser feita por IH e histologia. Concluímos que a frequiência do parvovírus B19 é similar à literatura e a reação IH foi o melhor método de detecção, com identificação mais específica e segura, permitindo identificação citoplasmática, o que não é possível pelo exame histopatológico. A PCR pode apresentar falsa negatividade, provavelmente pela fixação, não identifica as células e é mais dispendiosa. Embora mais específica e sensível em material a fresco ou idealmente fixado isto não ocorre com tecidos fixados em formalina e embebidos em parafina, freqüentemente os únicos disponíveis.

\section{ACKNOWLEDGMENTS}

The authors would like to thank Deise Lucia Chesca Simões for her technical assistance and to Mr. Jefferson Boyles for revising the manuscript.

\section{REFERENCES}

1. ANDERSON, M.J. \& COHEN, B.J. - Human parvovirus B19 infections in United Kingdom 1984-86. Lancet, 1: 738-739, 1987.

2. BROWN, K.E. \& YOUNG, N.S. - Parvovirus B19 in human disease. Ann. Rev. Med., 48: 59-67, 1997.

3. BROWN, T.; ANAND, A.; RITCHIE, L.D.; CLEWLEY, J.P. \& REID, T.M. - Intrauterine parvovirus infection associated with hydrops fetalis. Lancet, 2: 1033-1034, 1984

4. COHEN, B.J. \& BUCKLEY, M.M. - The prevalence of antibody to human parvovirus B19 in England and Wales. J. med. Microbiol., 25: 151-153, 1988.

5. COSSART, Y.E.; FIELD, A.M.; CANT, B. \& WIDDONS, D. - Parvovirus-like particles in human sera. Lancet, 1(7898): 72-73, 1975.

6. CUBEL, R.C.N.; GARCIA, A.G.P.; PEGADO, C.S. et al. - Human parvovirus B19 infection and hydrops fetalis in Rio de Janeiro, Brazil. Mem. Inst. Oswaldo Cruz, 91: 147-151, 1996.

7. ENDERS, G. \& BIBER, M. - Parvovirus B19 infections in pregnancy. Behring Inst. Mitt., 85: 74-78, 1990.

8. FERRE, F. \& GARDUNO, F. - Detection of human papillomavirus types 6/11, 16, and 18 using the polymerase chain reaction. Cancer Cells, 7: 215-218, 1989.

9. GARCIA, A.G.P.; PEGADO, C.S.; CUBEL, R.C.N. et al. - Feto-placentary pathology in human parvovirus B19 infection. Rev. Inst. Med. trop. S. Paulo, 40: 145-150, 1998.

10. GARCIA, R.C.N.C. - Parvoviridae. In : OLIVEIRA L.H.S. Virologia humana. Rio de Janeiro, Cultura Medica, 1994. p. 258-268.

11. GRATACÓS, E.; TORRES, P.J.; VIDAL, J. et al. - The incidence of human parvovirus B19 infection during pregnancy and its impact on perinatal outcome. J. infect. Dis., 171: 1360-1363, 1995. 
12. GREER, C.E.; WHEELER, C.M. \& MANOS, M.M. - PCR amplification from paraffinembedded tissues: sample preparation and the effects of fixation. In: DIEFFENBACH, C.W. \& DVEKSLER G.S., ed. PCR primer: a laboratory manual. Cold Spring Harbor, Cold Spring Harbor Lab. Press, 1995. p. 99-112.

13. HEEGAARD, E.D.; HASLE, H.; SKIBSTED, L.; BOCK, J. \& BROWN, K.E. - Congenital anemia caused by parvovirus B19 infection. Pediat. infect. Dis. J., 19: 1216-1218, 2000 .

14. HEEGAARD, E.D.; PETERSEN, B.L.; HEILMANN, C.J. \& HORNSLETH, A. Prevalence of parvovirus B19 and parvovirus V9 DNA and antibodies in paired bone marrow and serum samples from healthy individuals. J. clin. Microbiol., 40: 933-936, 2002.

15. JORDAN, J.A. \& DELOIA, J.A. - Globoside expression within the human placenta Placenta, 20: 103-108, 1999.

16. KARLSEN, F.; KALANTARI, M.; CHITEMERERE, M.; JOHANSSON, B. \& HAGMAR, B. - Modifications of human and viral deoxyribonucleic acid by formaldehyde fixation. Lab. Invest., 71: 604-611, 1994.

17. KNOLL, A.; LOUWEN, F.; KOCHANOWSKI, B. et al. - Parvovirus B19 infection in pregnancy: quantitative viral DNA analysis using a kinetic fluorescence detection system (TaqMan PCR). J. med. Virol., 67: 259-266, 2002.

18. MA, T.S. - Applications and limitations of polymerase chain reaction amplification. Chest, 108: $1393-1404,1995$

19. McCARTER-SPAULDING, D. - Parvovirus B19 in pregnancy. J. Obstet. Gynec. Neonat. Nurs., 31: 107-112, 2002.

20. MOREY, A.L.; O'NEILL, H.J.; COYLE, P.V. \& FLEMING, K.A. - Immunohistological detection of human parvovirus B19 in formalin-fixed, paraffin-embedded tissues. J. Path., 166: 105-108, 1992.

21. MUSIANI, M.; ZERBINI, M.; GENTILONI, G. et al. - Parvovirus B19 clearance from peripheral blood after acute infection. J. infect. Dis., 172: 1360-1363, 1995.

22. MUZYCZKA, N. \& BERNS, K.J. - Parvoviridae: the viruses and their replication. In: KNIPE, D.M.; HOWLEY, P.M.; GRIFFIN, D.E. et al. Virology. 4. ed. Philadelphia, Raven Press, 2001. p. 1017-1036.

23. NASCIMENTO, J.P.; BUCKLEY, M.M.; BROWN, K.E. \& COHEN, B.J. - The prevalence of antibody to human parvovirus B19 in Rio de Janeiro, Brazil. Rev. Inst. Med. trop. S. Paulo, 32: 41-45, 1990.
24. OLIVEIRA, S.A.; CAMACHO, L.A.B.; PEREIRA, A.C.M. et al. - Clinical and epidemiological aspects of human parvovirus B19 infection in an urban area in Brazil (Niterói city area, State of Rio de Janeiro, Brazil). Mem. Inst. Oswaldo Cruz, 97: 965-970, 2002.

25. O'MALLEY, A.; BARRY-KINSELLA, C.; HUGHES, C. et al. - Parvovirus infects cardiac myocytes in hydrops fetalis. Pediat. develop. Path., 6: 414-420, 2003.

26. PATOU, G.; PILLAY, D.; MYINT, S. \& PATTISON, J. - Characterization of a nested polymerase chain reaction assay for detection of parvovirus B19. J. clin. Microbiol., 31: 540-546, 1993.

27. ROGERS, B.B.; SINGER, D.B.; MAK, S.K. et al. - Detection of human parvovirus B19 in early spontaneous abortuses using serology, histology, electron microscopy, in situ hybridization, and the polymerase chain reaction. Obstet. Gynec., 81: 402408, 1993.

28. TOLFVENSTAM, T.; PAPADOGIANNAKIS, N.; NORBECK, O.; PETERSSON, K. \& BROLIDEN, K. - Frequency of human parvovirus B19 infection in intrauterine fetal death. Lancet, 357: 1494-1497, 2001.

29. TOROK, T.J. - Parvovirus B19 and human disease. Advanc. intern. Med., 37: 431-455, 1992.

30. VOGEL, H.; KORNMAN, M.; LEDET, S.C. et al. - Congenital parvovirus infection. Pediat. Path. Lab. Med., 17: 903-912, 1997.

31. WEILAND, H.T.; VERMEY-KEERS, C.; SALIMANS, M.M.M. et al. - Parvovirus B19 associated with fetal abnormality. Lancet, 1(8534): 682-683, 1987.

32. WRIGHT, C.; HINCHLIFFE, S.A. \& TAYLOR, C. - Fetal pathology in intrauterine death due to parvovirus B19 infection. Brit. J. Obstet. Gynaecol., 103: 133-136, 1996.

33. ZAKRZEWSKA, K.; AZZI, A.; DE BIASI, E. et al. - Persistence of parvovirus B19 DNA in synovium of patients with haemophilic arthritis. J. med. Virol., 65: 402407, 2001.

Received: 16 March 2006

Accepted: 31 August 2006 